\title{
Feeding physiology of infaunal (Mulinia edulis) and epifaunal (Mytilus chilensis) bivalves under a wide range of concentrations and qualities of seston
}

\author{
L. A. Velasco*, J. M. Navarro \\ Instituto de Biología Marina ‘Dr. Jürgen Winter', Universidad Austral de Chile, Casilla 567, Valdivia, Chile
}

\begin{abstract}
A comparative study was carried out on the functional feeding behavior of the infaunal clam Mulinia edulis and the epifaunal mussel Mytilus chilensis from Yaldad Bay, southern Chile, in response to broad fluctuations in quantity and quality of seston. A number of physiological variables were quantified and compared, including clearance, filtration and ingestion rates; pseudofeces production and pre-ingestive selection efficiency. Relative sizes of the ctenidia and labial palps were measured for both species to determine if the size of the organs was related to their capacity for filtration and pre-ingestive particle selection. Both species showed high rates of clearance at lower seston concentrations $\left(<3\right.$ to $\left.5 \mathrm{mg} \mathrm{l}^{-1}\right)$. Above these concentrations, both species regulated both the quantity and quality of material ingested. When the seston concentration was relatively low and/or its quality high, regulation of food ingested was accomplished primarily by reduction in clearance rate, while at high seston concentrations and/or low quality, this parameter was regulated primarily by the expulsion of pseudofeces with a lower content of organic matter. Ingestion regulation was higher in $M$. chilensis. In general, both species showed a capacity for pre-ingestive particle selection, which increased with seston concentration and the proportion of organic matter present. In diets containing more than $60 \%$ organic matter, selection efficiency in $M$. chilensis became slightly reduced, while in M. edulis it remained stable; this observation is explained by the larger relative size of the labial palps in Mulinia edulis. Generally, feeding rates of M. chilensis were higher than those of M. edulis; this may be attributable to the former's larger-sized ctenidia, which are able to filter more food.
\end{abstract}

KEY WORDS: Mulinia edulis · Mytilus chilensis · Infaunal and epifaunal bivalves · Feeding behavior · Particle selection $\cdot$ Diet quality $\cdot$ Chile tidal flats

\section{INTRODUCTION}

Numerous species of bivalve filter-feeders inhabit the estuaries and tidal flats in southern Chile, often at high population densities. The seston in these regions, upon which the bivalves feed, commonly undergoes major fluctuations in concentration and quality, as it participates in sedimentation and resuspension cycles produced by the extreme tidal ranges in this ecosystem (Rojas 1984, Navarro et al. 1993). One of the bivalves

${ }^{*}$ Present address: Instituto de Investigaciones Tropicales, Universidad del Magdalena, Av. Ferrocarril, Santa Marta, Colombia. E-mail: luza.velasco@unimag.edu.co present is the infaunal clam Mulinia edulis King, 1831, which inhabits the low intertidal zone (Jaramillo et al. 1985, Asencio et al. 1993). Also present in this region is the epibenthic mussel Mytilus chilensis Hupe, 1854, which lives attached to hard substrates in the mediumhigh intertidal zone (Winter et al. 1982). M. edulis is exposed to greater fluctuations in seston than $M$. chilensis, as the former occupies very fine sediments that are more easily resuspended than those of the coarser sands around mussel habitats (Winter et al. 1982, Clasing et al. 1998).

Numerous studies have examined the feeding physiology of filter-feeding bivalves as it relates to the concentration and quality of the seston (Winter 1970, 
Foster-Smith 1975, Kiørboe \& Møhlenberg 1981, Newell \& Jordan 1983, Iglesias et al. 1992, 1996, Navarro et al. 1992, 1994, Ward \& MacDonald 1996, Navarro \& Widdows 1997). These studies suggest that both infaunal and epifaunal bivalves are able to affect pre-ingestive particle selection, which improves the quality of the matter ingested. In this manner, these organisms are able to adjust their feeding rates in order to maximise their acquisition of energy and avoid functional problems associated with particle saturation. A majority of studies on this topic were carried out using a narrow range of seston concentrations ( 2 to $30 \mathrm{mg} \mathrm{l}^{-1}$ ) in seawater that did not necessarily reflect natural seston concentrations, which may range to over $100 \mathrm{mg} \mathrm{l}^{-1}$ with extreme values of $500 \mathrm{mg} \mathrm{l}^{-1}$ (Falconer \& Owens 1990). The few studies which have included high ranges of seston concentration ( $>100 \mathrm{mg} \mathrm{l}^{-1}$ ) used natural seston or diets made up of varying quantities of sediment to which known amounts of phytoplankton had been added (Widdows et al. 1979, Hawkins et al. 1996, Urrutia et al. 1996, Navarro \& Widdows 1997). In these studies, the concentration of seston was inversely correlated with the proportion of organic matter, and thus the physiological responses recorded were difficult to interpret due to simultaneous changes in the quality and quantity of the seston.

The present laboratory study was carried out using cultured algae mixed with natural fine sediment to elucidate the functional responses of infaunal (Mulinia edulis) and epibenthic (Mytilus chilensis) bivalves exposed to broad fluctuations in the availability and quality of food material in the seston. Measurements were made on several physiological variables related to feeding, including clearance, filtration and ingestion rates, production of pseudofeces and pre-ingestive selection efficiency. Other measurements included areas of the ctenidia and labial palps of these bivalves to determine any relationship between the size of these organs and their relative capacity for filtration and pre-ingestive selection of particles from the seston.

\section{MATERIALS AND METHODS}

Collection and acclimation of bivalves. Adult Mulinia edulis and Mytilus chilensis were collected from the tidal flat at Yaldad Bay, Chile $\left(43^{\circ} 08^{\prime} \mathrm{S}\right.$; $73^{\circ} 44^{\prime} \mathrm{W}$ ) and maintained in continuously flowing natural seawater enriched with laboratory-cultured microalgae (Isochrysis galbana) at $14^{\circ} \mathrm{C}$ and a salinity of $30 \%$, which represented typical annual averages for this bay (Navarro et al. 1993). Thirty specimens of each species were collected, with $M$. edulis individuals measuring $50.2 \pm 1.1 \mathrm{~mm}$ in length and $1.36 \pm 0.36 \mathrm{~g}$ in dry tissue weight, and the $M$. chilensis individuals measuring $50.7 \pm 0.7 \mathrm{~mm}$ and $1.04 \pm 0.36 \mathrm{~g}$ dry tissue weight.
Feeding experiments. Experimental diets were prepared by mixing cultured microalgae (Isochrysis galbana) with natural sediment collected from the top $(0.5 \mathrm{~cm})$ of the tidal flat at Yaldad, with the aim of simulating ranges of concentration and organic matter content typically measured at this location. The sediment was diluted in seawater and screened through a $40 \mu \mathrm{m}$ mesh screen. The microalgae were cultured in $\mathrm{f} / 2$ medium (Guillard 1974) and had a particle size ranging between 3 and $7 \mu \mathrm{m}$ spherical diameter; they contained 70 to $90 \%$ organic material. The sediment particles were in the 3 to $15 \mu \mathrm{m}$ size range and contained 13 to $15 \%$ organic material; $100 \%$ of the microalgae particles were smaller than $7 \mu \mathrm{m}$, whereas only $80 \%$ of the sediment particles were smaller than $7 \mu \mathrm{m}$. Quantification of the contents of each diet was as follows: the number of particles equivalent to $1 \mathrm{mg}$ dry weight was determined on 3 replicates of each basic solution of algae and sediment, with each replicate divided into 2 subsamples. Of these 2 subsamples, 1 was analyzed with an ELZONE $180 \mathrm{XY}$ particle counter using an aperture opening of $120 \mu \mathrm{m}$ (detecting particles between 2.9 and $75.6 \mu \mathrm{m}$ diameter) which estimated the total particulate matter (TPM) as particles per liter. The second subsample was analyzed for total dry weight and particulate organic matter using the methods of Strickland \& Parsons (1972). Each subsample was filtered on glass-fiber filters (diameter $=0.45 \mu \mathrm{m}$; Millipore) which had been previously washed with distilled water, ashed at $450^{\circ} \mathrm{C}$ for $4 \mathrm{~h}$, and weighed. The filtrate was washed with $3 \%$ ammonium formate, dried at $70^{\circ} \mathrm{C}$ for $48 \mathrm{~h}$, and weighed; the net dry weight represented the total seston (TPM, $\mathrm{mg} \mathrm{l}^{-1}$ ) in the diet. The particulate organic material (POM) content of the samples was determined from the ash-free dry weight, obtained by ashing the filters at $450^{\circ} \mathrm{C}$ for $4 \mathrm{~h}$ and re-weighing.

A total of 48 feeding experiments were carried out, each consisting of a different diet, with variations between 1.91 and $203.13 \mathrm{mg} \mathrm{l}^{-1}$ and organic material percentages between 18 and $91 \%$. Each experiment lasted $5 \mathrm{~h}$; the first $2 \mathrm{~h}$ were used to acclimate the bivalves to the diet, and physiological measurements were made during the subsequent $3 \mathrm{~h}$. The acclimation time represented the time required for ingested particles to appear in the feces of the organisms, determined using particles containing fluorescent markers. This assured that the digestive tract contained particles of the experimental diet being tested. Diets were administered using an open system comprising 18 bivalve chambers, a constant flow of seawater, a vessel containing the basic diet (sediment + microalgae), and a peristaltic pump that delivered measured dosages to a mixing chamber from which the diet flowed continuously to each chamber containing the test bivalves. Each experiment was comprised of 8 replicates per species and a control chamber, which contained a pair of empty valves of the 
corresponding species in order to correct for the retention and/or sedimentation of particles in the chambers arising from physical factors.

Physiological measurements. Clearance, filtration, rejection and ingestion rates were carried out as follows.

Clearance rate: This rate was determined by measuring the difference between particles in the control chambers $\left(C_{1}\right)$ and experimental chambers, each containing a bivalve $\left(C_{2}\right)$ every 30 min during each experiment. At the same time, flow rate $(F)$ was determined for each chamber, and a difference of 20 to $40 \%$ in particle numbers was maintained between the chambers containing bivalves and the control chambers as described by Navarro \& Thompson (1996). Clearance rate (CR) was calculated from:

$$
\mathrm{CR}\left(1 \mathrm{~h}^{-1}\right)=F \times\left[\left(C_{1}-C_{2}\right) / C_{1}\right]
$$

Filtration rate: The quantities of total (FR) and organic particulate matter (OFR) removed from the water per unit time were estimated from the following equations (Widdows 1985):

$$
\begin{aligned}
\text { FR }\left(\mathrm{mg} \mathrm{h}^{-1}\right) & =\mathrm{CR} \times \mathrm{TPM} \\
\mathrm{OFR}\left(\mathrm{mg} \mathrm{h}^{-1}\right) & =\mathrm{CR} \times \mathrm{POM}
\end{aligned}
$$

Rejection rate and pre-ingestive selection efficiency: At the end of each experiment, pseudofeces were collected quantitatively with Pasteur pipettes, and their dry weight and organic matter content were measured following the same methods as described for the seston. The rate of total production of pseudofeces and organic matter (RR and ORR, $\mathrm{mg} \mathrm{h}^{-1}$ ) were calculated by dividing the total pseudofeces produced by the time of duration of each experiment.

The efficiency of pre-ingestive selection (SE) represented the efficiency with which particles of higher organic content were retained for ingestion. This was calculated after Bayne et al. (1993) as:

$$
S E=1-(p / f) \times 100
$$

where $p=\%$ organic matter in pseudofeces and $f=$ $\%$ organic matter in the diet.

Ingestion rate: When no pseudofeces were produced, the total filtration and organic filtration rates represented the total ingestion rate (IR) and organic ingestion rate (OIR), respectively. With concurrent pseudofeces production, the ingestion rate was calculated by subtracting the total pseudofeces production rate $(\mathrm{RR})$ or the organic pseudofeces production rate (ORR) (Bayne et al. 1993):

$$
\begin{aligned}
\operatorname{IR}\left(\mathrm{mg} \mathrm{h}^{-1}\right) & =\mathrm{FR}-\mathrm{RR} \\
\mathrm{OIR}\left(\mathrm{mg} \mathrm{h}^{-1}\right) & =\mathrm{OFR}-\mathrm{O}
\end{aligned}
$$

Area of pallial organs. Thirteen specimens of $\mathrm{Mu}$ lina edulis (length $=51.89 \pm 0.59 \mathrm{~mm}$ ) and 15 Mytilus chilensis (length $=50.69 \pm 0.86 \mathrm{~mm}$ ) obtained from the Yaldad tidal flats were dissected to obtain the ctenidia and labial palps. The organs from individual specimens were spread on a flat surface and photographed and their surface areas were then determined using a Scion image program Version 3.0b.

Standardization and transformation of variables. The physiological rates and areas of pallial organs were converted to a 'standard' individual of $1 \mathrm{~g}$ tissue weight; for this, the soft tissues were dried at $70^{\circ} \mathrm{C}$ for $48 \mathrm{~h}$ and then individually weighed. Standardization employed the equation of Bayne et al. (1987):

$$
Y_{\mathrm{s}}=\left(W_{\mathrm{s}} / W_{\mathrm{e}}\right)^{b} \times Y_{\mathrm{e}}
$$

where $Y_{\mathrm{s}}=$ the clearance rate or area of pallial organs for an individual of standard weight, $W_{\mathrm{s}}=$ its standard weight, $W_{\mathrm{e}}=$ its observed weight, $Y_{\mathrm{e}}=$ the uncorrected measured clearance rate or area of its pallial organs, and $b=$ the weight exponent. The weight exponents for clearance rates were 0.5 and 0.61 for Mulinia edulis and Mytilus chilensis, respectively. For the pallial organ area in both species, the weight exponents used were 0.1 and 0.61 for ctenidia and palps, respectively.

Statistical analysis. Tests for normality and homocedasticity were carried out on the physiological variables according to Sokal \& Rohlf (1979). Clearance, filtration, and ingestion were $\log _{10}$-transformed, production of pseudofeces was transformed to square roots, and an arcsine transformation was applied to the selection efficiency data. Multiple linear and nonlinear regression analyses were carried out to determine the dependency of the physiological variables on the concentration and/or the quality of the seston. Analyses of covariance were applied to detect differences between the physiological variables between the 2 species. Finally, a 1-way ANOVA was carried out to reveal any differences between the organic fraction of the food and that of the pseudofeces produced by Mulinia edulis and Mytilus chilensis, as well as any differences between their pallial organ area. ANCOVA calculations were performed with the general linear model procedure (GLM) of the SAS 6.1 program (SAS Institute). The non-linear models and graphics were prepared using the least-squares estimation procedures and the quasi-Newton estimation method of the STATISTICA program. Significance levels were determined at $\alpha=0.05$.

\section{RESULTS}

\section{Clearance and filtration rates}

Over the range of seston concentration tested (1 to $200 \mathrm{mg} \mathrm{l}^{-1}$ ), the clearance rate for Mulinia edulis varied 
Table 1. Mulinia edulis and Mytilus chilensis. Regressions (mean \pm SE) between concentration of seston (total particulate matter, TPM), its organic content (particulate organic matter, POM) and feeding rates. CR: clearance rate; FR: total filtration rate; OFR: organic filtration rate; RR: rate of pseudofeces production; SE: efficiency of pre-ingestive selection; IR: total ingestion rate; OIR: organic ingestion rate

\begin{tabular}{|c|c|c|c|}
\hline Equation & $r^{2}$ & $\mathrm{p}<$ & $\mathrm{n}$ \\
\hline \multicolumn{4}{|l|}{ Mulinia edulis } \\
\hline $\mathrm{CR}=10^{\left(2.95[ \pm 0.11]-0.59[ \pm 0.02] \log _{10} \mathrm{TPM}-1.53[ \pm 0.07] \log _{10} \mathrm{POM}\right)}$ & 0.815 & 0.0001 & 341 \\
\hline 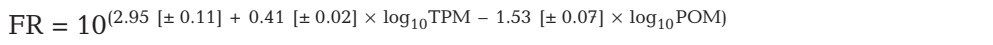 & 0.815 & 0.0001 & 341 \\
\hline $\mathrm{OFR}=10^{\left(1.15[ \pm 0.13]+0.38[ \pm 0.02] \times \log _{10} \mathrm{TPM}-0.61[ \pm 0.08] \times \log _{10} \mathrm{POM}\right)}$ & 0.671 & 0.0001 & 341 \\
\hline $\begin{aligned} \mathrm{RR}= & \left(-9.75[ \pm 1.36]+17.77[ \pm 0.97] \log _{10} \mathrm{TPM}+5.19[ \pm 0.85] \log _{10} \mathrm{POM}\right. \\
& \left.-9.18[ \pm 0.63] \log _{10} \mathrm{TPM} \times \log _{10} \mathrm{POM}\right)^{2}\end{aligned}$ & 0.908 & 0.0001 & 273 \\
\hline $\begin{aligned} \mathrm{SE}= & 100 \times \sin \left(-5.41[ \pm 1.60]+1.66[ \pm 0.54] \times \log _{10} \mathrm{TPM}+5.19[ \pm 1.75]\right. \\
& \times \log _{10} \mathrm{POM}-0.62[ \pm 0.27] \times \log _{10} \mathrm{TPM} \times \log _{10} \mathrm{POM}-0.20[ \pm 0.07] \\
& \left.\times\left[\log _{10} \mathrm{TPM}\right]^{2}-1.16[ \pm 0.50] \times\left[\log _{10} \mathrm{POM}\right]^{2}\right)\end{aligned}$ & 0.255 & 0.0229 & 180 \\
\hline $\left.\mathrm{IR}=10^{(1.09}[ \pm 0.11]+0.57[ \pm 0.13] \times \log _{10} \mathrm{TPM}-0.16[ \pm 0.06] \times \log _{10} \mathrm{TPM}^{2}-0.26[ \pm 0.03] \times\left[\log _{10} \mathrm{POM}\right]\right)$ & 0.528 & 0.0044 & 211 \\
\hline $\mathrm{OIR}=0.69( \pm 0.19)+2.69( \pm 0.17) \times \log _{10} \mathrm{TPM}$ & 0.532 & 0.0001 & 211 \\
\hline \multicolumn{4}{|l|}{ Mytilus chilensis } \\
\hline 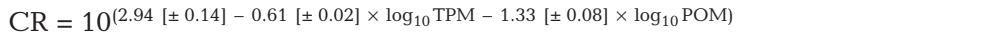 & 0.826 & 0.0001 & 274 \\
\hline 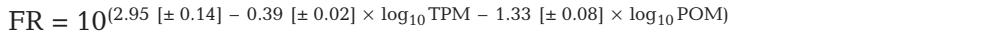 & 0.753 & 0.0001 & 274 \\
\hline $\mathrm{OFR}=10^{\left(0.96[ \pm 0.14]+0.39[ \pm 0.012] \times \log _{10} \mathrm{TPM}-0.39[ \pm 0.08] \times \log _{10} \mathrm{POM}\right)}$ & 0.597 & 0.0001 & 274 \\
\hline $\mathrm{RR}=\left(14.71[ \pm 0.58]-7.08[ \pm 0.39] \log _{10} \mathrm{TPM} \times \log _{10} \mathrm{POM}\right)^{2}$ & 0.875 & 0.0001 & 239 \\
\hline $\begin{aligned} \mathrm{SE}= & 100 \times \sin \left(-6.95[ \pm 1.18]+1.43[ \pm 0.29] \times \log _{10} \mathrm{TPM}+7.68[ \pm 1.38]\right. \\
& \times \log _{10} \mathrm{POM}-0.45[ \pm 0.15] \times \log _{10} \mathrm{TPM} \times \log _{10} \mathrm{POM}-0.25[ \pm 0.04] \\
& \left.\times\left[\log _{10} \mathrm{TPM}\right]^{2}-2.08[ \pm 0.41] \times\left[\log _{10} \mathrm{POM}\right]^{2}\right)\end{aligned}$ & 0.328 & 0.0026 & 289 \\
\hline $\begin{aligned} \mathrm{IR}= & 0.18( \pm 0.02) \times \log _{10} \mathrm{TPM}+0.35( \pm 0.02) \times \log _{10} \mathrm{POM}-0.0007( \pm 0.0001) \\
& \times\left(\log _{10} \mathrm{TPM}\right)^{2}-0.004( \pm 0.0004) \times\left(\log _{10} \mathrm{POM}\right)^{2}\end{aligned}$ & 0.363 & 0.0001 & 167 \\
\hline $\begin{aligned} \mathrm{OIR}= & -5.41( \pm 1.33)+0.17( \pm 0.01) \times \mathrm{TPM}+0.35( \pm 0.06) \\
& \times \mathrm{POM}-0.0007( \pm 0.0001) \times \mathrm{TPM}^{2}-0.003( \pm 0.0034) \times \mathrm{POM}^{2}\end{aligned}$ & 0.594 & 0.0001 & 167 \\
\hline
\end{tabular}

Mulinia edulis

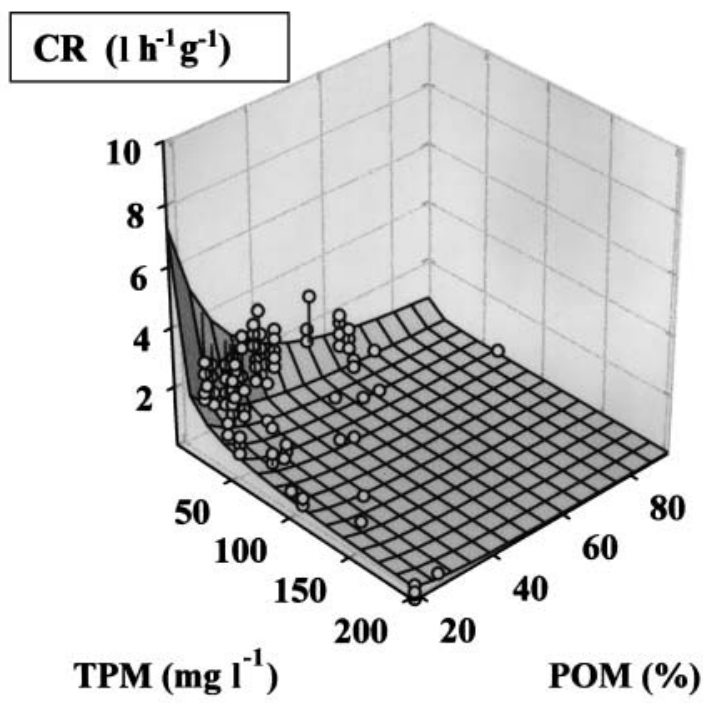

Mytilus chilensis

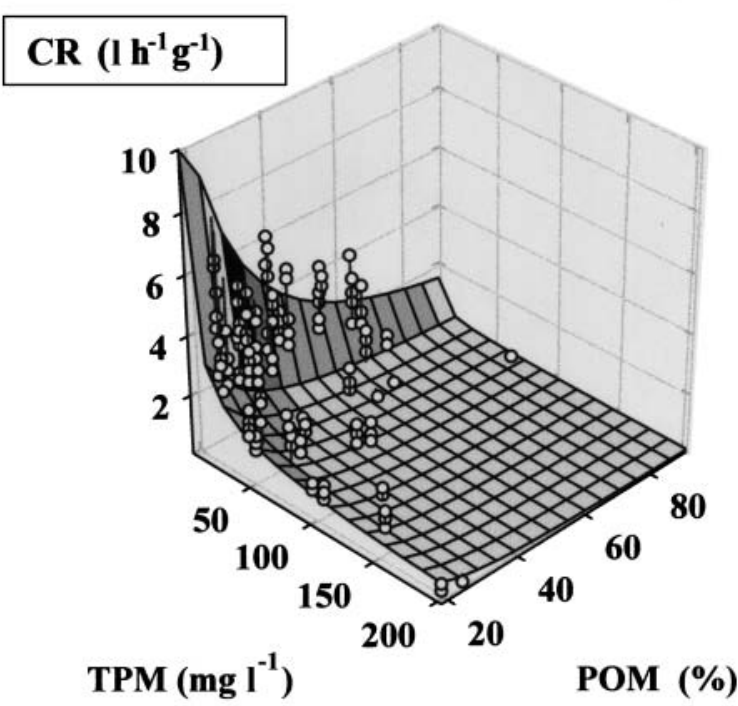

Fig. 1. Mulinia edulis and Mytilus chilensis. Relation between concentration of seston (TPM), its organic content (POM) and clearance rate $(\mathrm{CR})$ 
between 0.05 and $2.22 \mathrm{l} \mathrm{h}^{-1} \mathrm{~g}^{-1}$ while that of Mytilus chilensis was between 0.05 and $4.40 \mathrm{l} \mathrm{h}^{-1} \mathrm{~g}^{-1}$. These values declined with increasing concentration of the seston and increasing percentage of the organic content of the seston (Fig. 1). The regression models that were best fitted to the effect of concentration and quality of the diet on the clearance rates are described by the equations in Table 1. Although the tendency appeared the same for both species, the ANCOVA demonstrated that the clearance rate of $M$. chilensis was significantly higher than that of $M$. edulis (Table 2) at any given seston concentration.

Over the spectrum of seston concentrations tested, the total filtration rate of Mulinia edulis varied between 2.65 and $144.19 \mathrm{mg} \mathrm{h}^{-1} \mathrm{~g}^{-1}$ and that of Mytilus chilensis between 3.28 and $189.81 \mathrm{mg} \mathrm{h}^{-1} \mathrm{~g}^{-1}$ (Fig. 2).
The organic filtration rate of $M$. edulis fluctuated between 1.33 and $17.09 \mathrm{mg} \mathrm{h}^{-1} \mathrm{~g}^{-1}$ while that of $M$. chilensis ranged between 2.93 and $35.07 \mathrm{mg} \mathrm{h}^{-1} \mathrm{~g}^{-1}$ (Fig. 2). In general terms, the total particulate matter and organic matter filtered by both species increased with increasing seston concentration. This increase was also noted when there was a decrease in the organic content of the seston (Fig. 2). The regression models that were best fitted to the effect of concentration and quality of the diet on the total and organic matter filtration rates are described by the equations in Table 1.

The ANCOVA showed that the rates of total and organic matter filtration by Mytilus chilensis were significantly greater than those of Mulinia edulis (Table 2).
Mulinia edulis
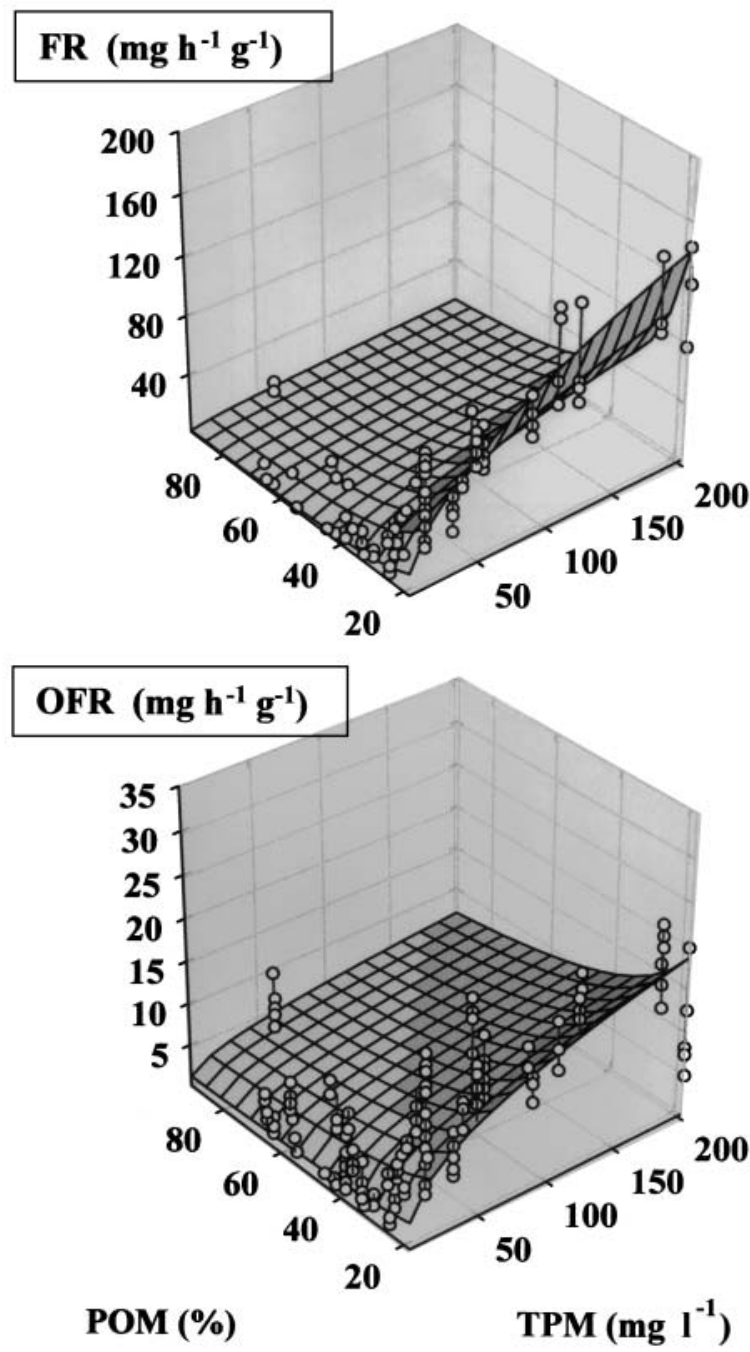

Mytilus chilensis
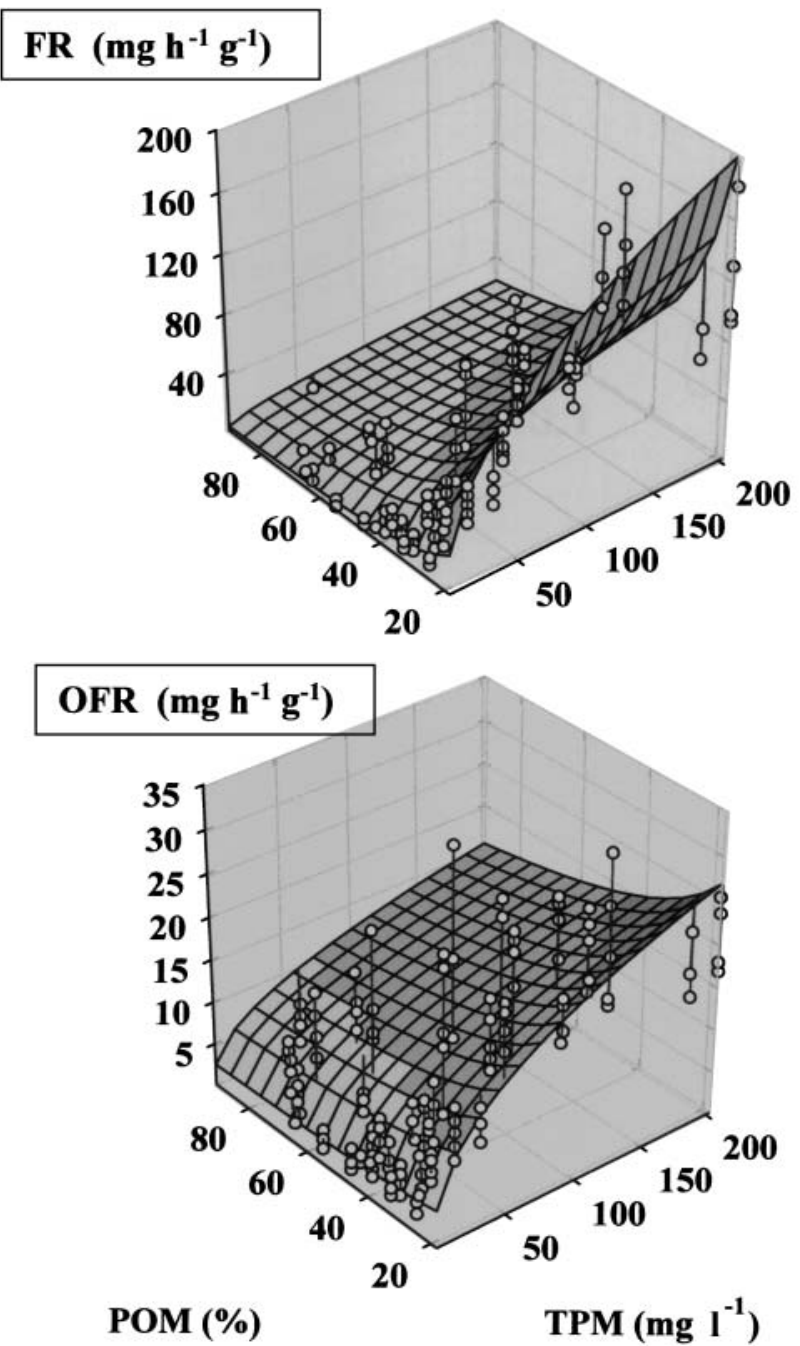

Fig. 2. Mulinia edulis and Mytilus chilensis. Relation between concentration of seston (TPM), its organic content (POM), total filtration rate (FR) and organic filtration rate (OFR) 
Table 2. Mulinia edulis and Mytilus chilensis. ANCOVA for physiological variables (GLM procedure; model: physiological variable $=$ species TPM or POM). p > IT| $H_{0}$ : probability of getting a larger $|\mathrm{T}|$ value under the hypothesis. (1) $M$. edulis and (2) $M$. chilensis. (A very small value for this probability leads to the conclusion that the independent variable contributes significantly to the model.) CR: clearance rate; FR: total filtration rate; OFR: organic filtration rate, RR: rate of pseudofeces production; SE: efficiency of pre-ingestive selection; IR: total ingestion rate; OIR: organic ingestion rate

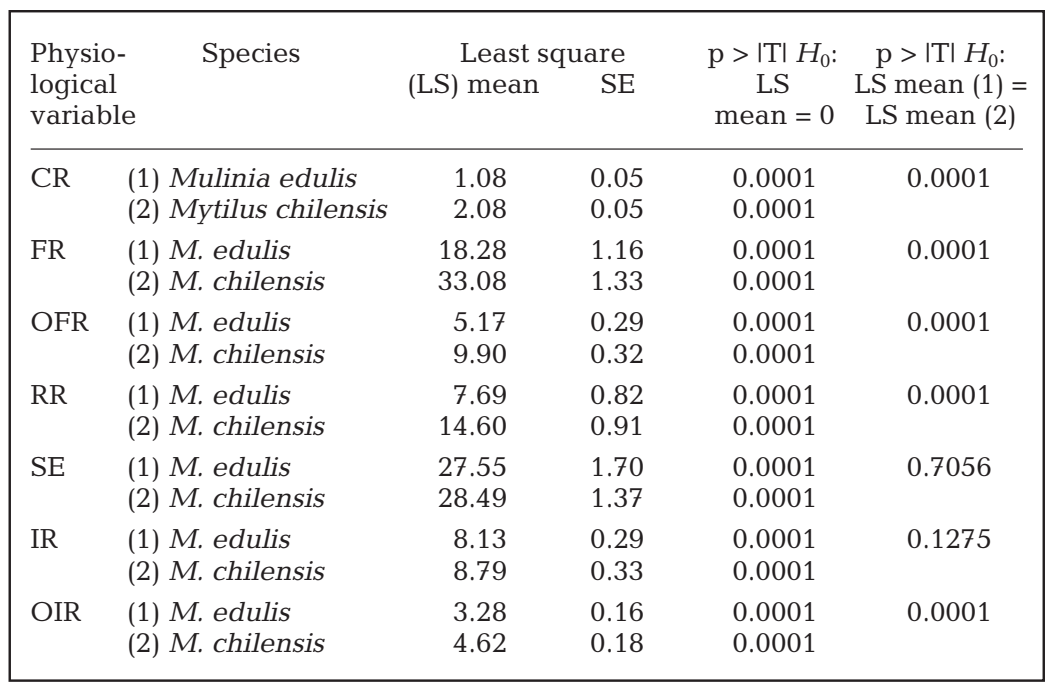

\section{Rejection rate}

Production of pseudofeces by Mulinia edulis began at seston concentrations just above $4.5 \mathrm{mg} \mathrm{l}^{-1}$ when the percentage of organic matter in the diet was $30 \%$, and at $6 \mathrm{mg} \mathrm{l}^{-1}$ when the organic content was $60 \%$. The production of pseudofeces in Mytilus chilensis occurred at seston concentrations just above $2.7 \mathrm{mg}$ $\mathrm{l}^{-1}$, with no apparent relation to organic matter content. At lower seston concentrations pseudofeces were produced sporadically in minor amounts; pseudofeces production increased as the amount of seston increased, and with a decrease in organic content (Fig. 3). The greatest production of pseudofeces occurred at $108.5 \mathrm{mg} \mathrm{l}^{-1}$ of seston for both species, reaching $134.5 \mathrm{mg} \mathrm{h}^{-1} \mathrm{~g}^{-1}$ in M. edulis and $177.4 \mathrm{mg} \mathrm{h}^{-1} \mathrm{~g}^{-1}$ in M. chilensis. The joint effect of concentration and quality of the diet on the production of pseudofeces is described in Table 1.

The ANCOVA showed significantly higher production of pseudofeces by Mytilus chilensis (Table 2).

\section{Pre-ingestive selection efficiency}

In both species, material rejected as pseudofeces had a significantly lower organic content than the diet offered $(p=0.001$; Fig. 4). Selection efficiency of the particles varied between -4 and $65 \%$ in Mulinia edulis and between 1 and $66 \%$ in Mytilus chilensis. In both species the selection efficiency increased with increasing concentration and organic fraction of the seston; however, at levels greater than $60 \%$ organic matter, M. chilensis showed a mild reduction in its selective capacity, while

\section{Mulinia edulis}

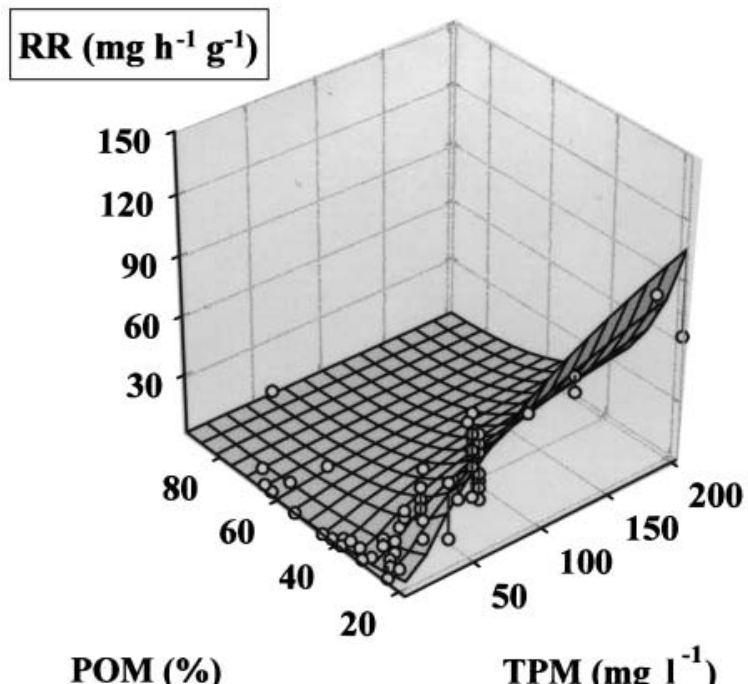

\section{Mytilus chilensis}

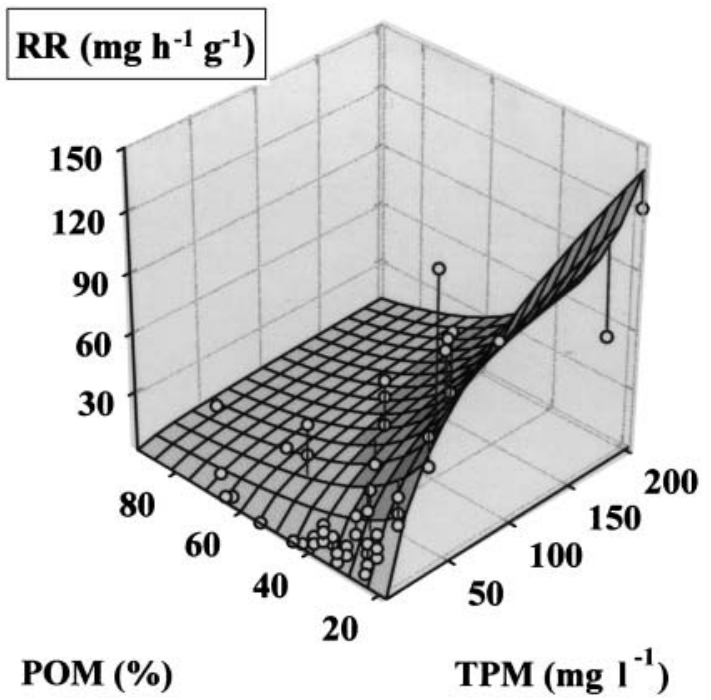

Fig. 3. Mulinia edulis and Mytilus chilensis. Relation between concentration of seston (TPM), its organic content (POM) and the rate of production of pseudofeces (RR) 
this parameter became stable in M. edulis (Fig. 5). Table 1 presents the equations which best describe the seston effects on selection efficiency.

ANCOVA revealed no significant differences between the selective efficiencies of the 2 species (Table 2).

\section{Ingestion rate}

Over the range of seston concentrations tested ( 1 to $200 \mathrm{mg} \mathrm{l}^{-1}$ ), the total ingestion rate fluctuated between 2.65 and $19.58 \mathrm{mg} \mathrm{h}^{-1} \mathrm{~g}^{-1}$ in Mulinia edulis and between 2.06 and $22.12 \mathrm{mg} \mathrm{h}^{-1} \mathrm{~g}^{-1}$ in Mytilus chilensis, whereas organic ingestion varied between 1.31 and $7.8 \mathrm{mg} \mathrm{h}^{-1} \mathrm{~g}^{-1}$ in $M$. edulis and between 2.02 and $15.65 \mathrm{mg} \mathrm{h}^{-1} \mathrm{~g}^{-1}$ in $M$. chilensis. The ingestion rate of $M$. edulis increased up to $10-20 \mathrm{mg} \mathrm{l}^{-1}$, and then remained stable at the higher concentrations. $M$. chilensis showed a sustained increase up to $100 \mathrm{mg} \mathrm{l}^{-1} \mathrm{~g}^{-1}$, decreasing thereafter (Fig. 6). An increase in total and organic ingestion with decreasing organic fraction of the diet was observed in both species except for the organic ingestion rate of $M$. edulis. In $M$. chilensis there was also a decline, with the seston containing less than $40 \%$ organic matter. The regression models which best describe these relations in the 2 species are detailed in Table 1.

The ANCOVA showed that there were no significant differences between total ingestion rates of the 2 species, whereas the organic ingestion rates of Mytilus chilensis was significantly higher than that of Mulinia edulis (Table 2).

\section{Mulinia edulis}

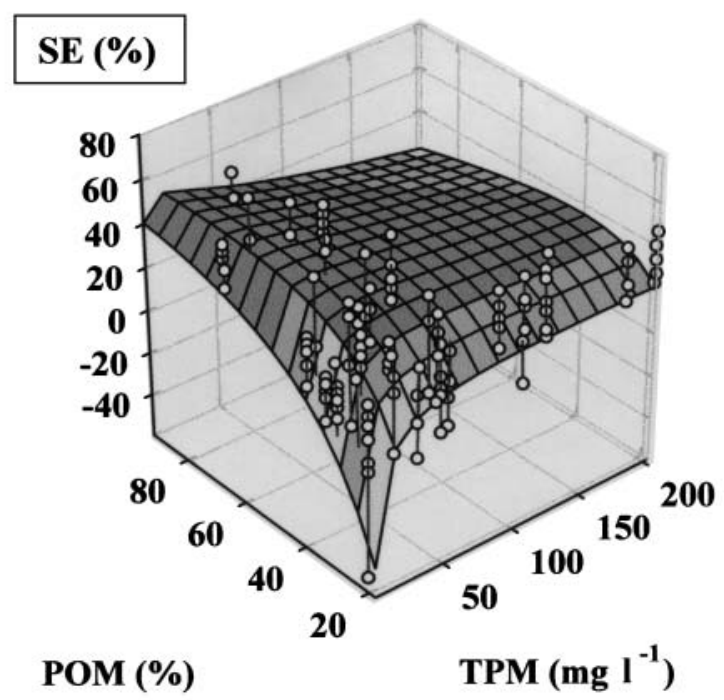

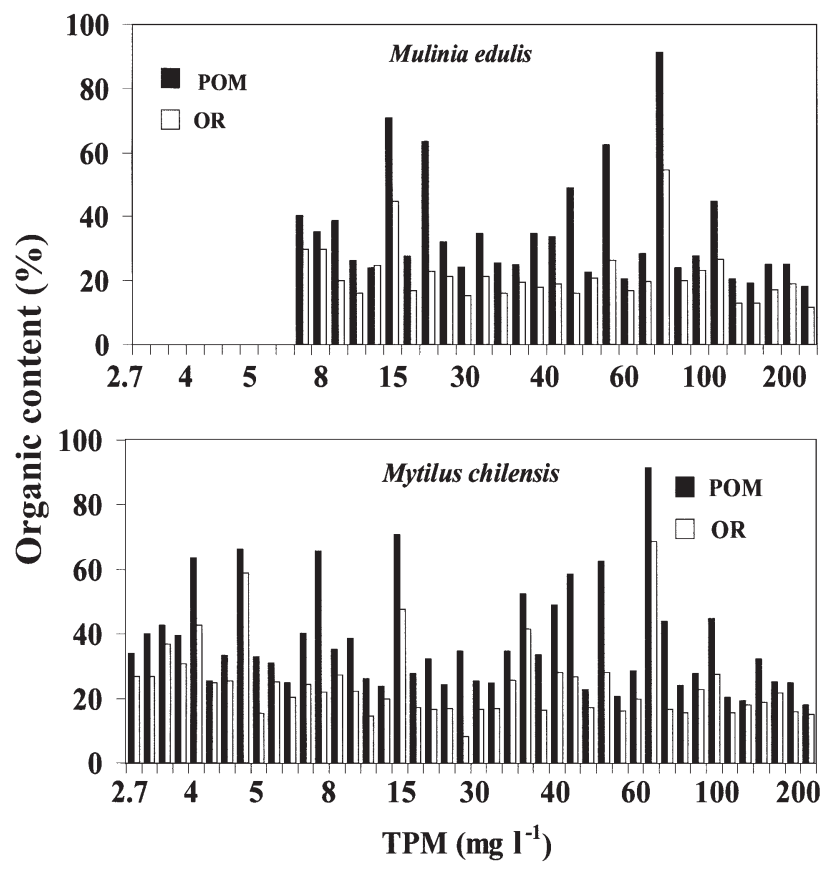

Fig. 4. Mulinia edulis and Mytilus chilensis. Relation between organic content of food (POM) and that of pseudofeces (OR) produced at different seston concentrations (TPM) in the laboratory

\section{Area of pallial organs}

In Mulinia edulis, the ctenidial area measured about $0.71 \mathrm{~mm}^{2} \mathrm{~g}^{-1}$, whereas this value was $1.29 \mathrm{~mm}^{2} \mathrm{~g}^{-1}$ for Mytilus chilensis. The labial palps of $M$. edulis mea-

\section{Mytilus chilensis}

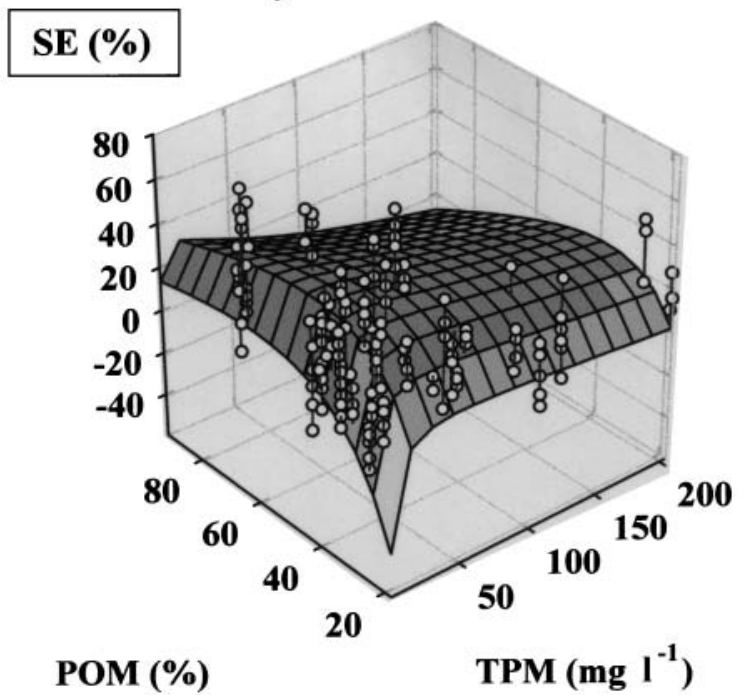

Fig. 5. Mulinia edulis and Mytilus chilensis. Relation between concentration of seston (TPM), its organic content (POM) and efficiency of pre-ingestive selection (SE) 
Mulinia edulis

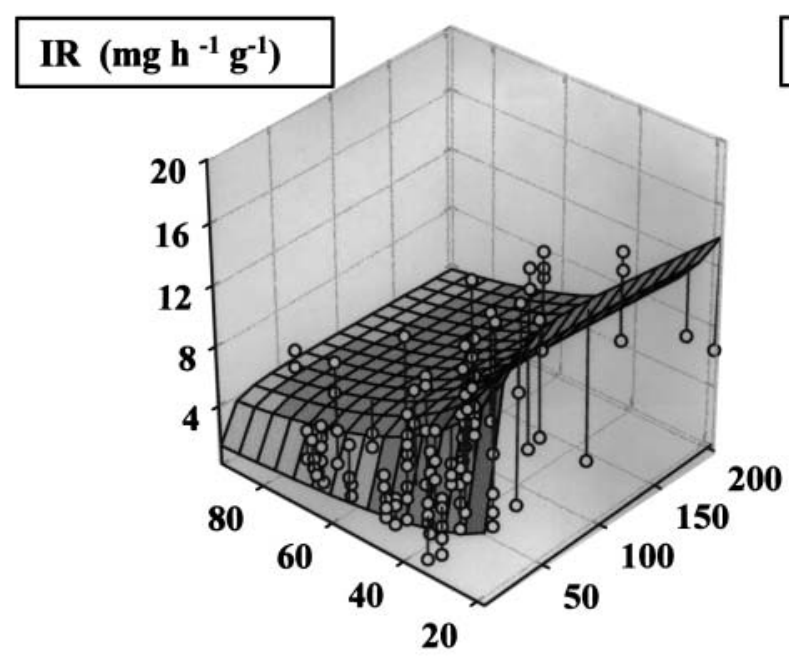

Mytilus chilensis

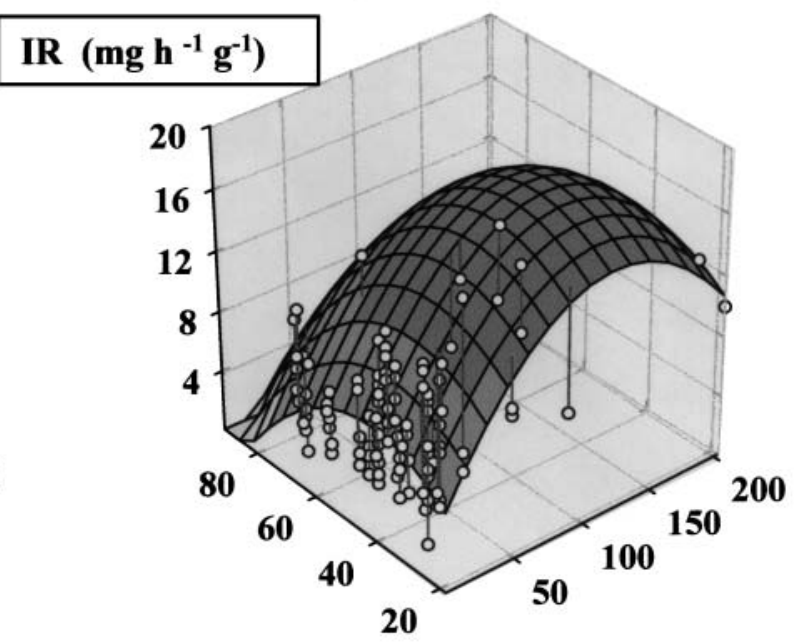

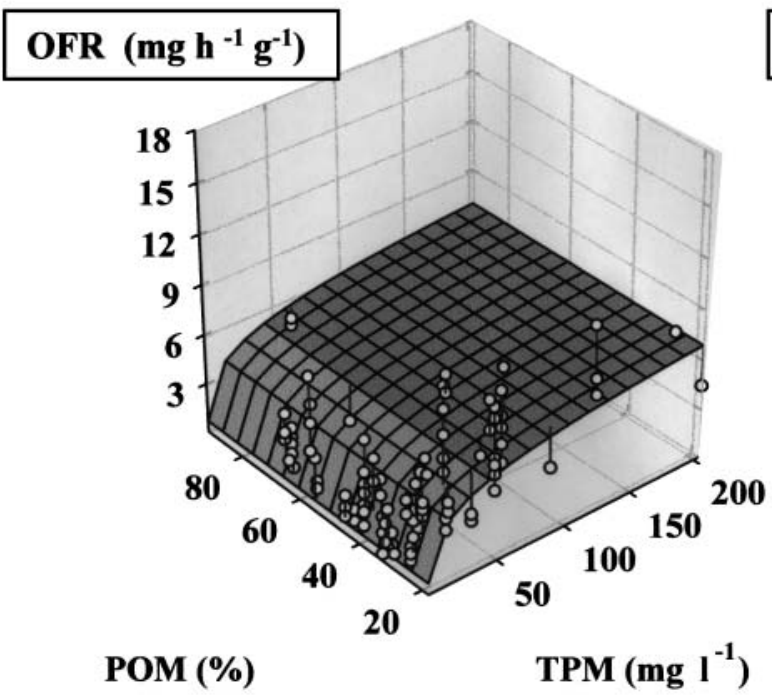

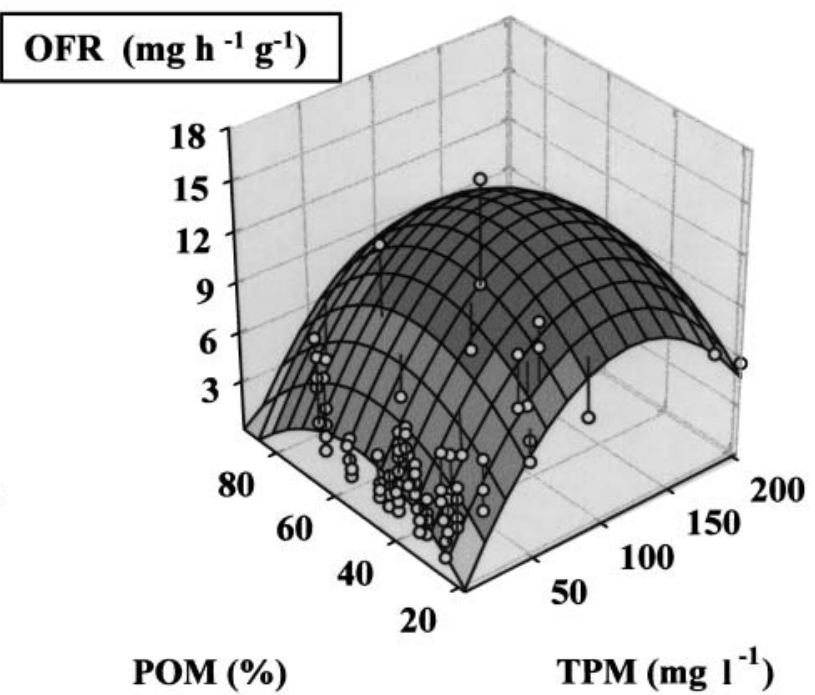

Fig. 6. Mulinia edulis and Mytilus chilensis. Relation between concentration of seston (TPM), its organic content (POM), rates of total ingestion (IR) and organic ingestion (OIR)

sured about $0.23 \mathrm{~mm}^{2} \mathrm{~g}^{-1}$ of the organism, while this parameter was $0.1 \mathrm{~mm}^{2} \mathrm{~g}^{-1}$ for $M$. chilensis. The ANCOVA showed that the ctenidial area of Mulinia was significantly higher than that of $M$. chilensis (df $=26, F=141.1, \mathrm{p}=0.0001$ ), while the labial palps area of $M$. edulis was significantly lower than that of M. chilensis ( $\mathrm{df}=26, F=57.4, \mathrm{p}=0.0001)$.

\section{DISCUSSION}

\section{Clearance and filtration rates}

The higher rates of clearance in Mulinia edulis and Mytilus chilensis with lower concentrations and qual- ity of seston has been observed in other bivalves, and has been explained as a mechanism for maximising food uptake during periods of limited food availability (Bayne et al. 1987, Willows 1992). The decrease in feeding rate with increased seston concentration may be a response mechanism for the regulation of ingestion rate to avoid saturation of the ctenidia and labial palps (Iglesias et al. 1992). The reduction in clearance rate with increasing seston quality has been described as a mechanism to conserve energy when pre-ingestive selection efficiency is irrelevant, as with monoalgal diets (Navarro et al. 1992). Thus, both species studied control the amount of particles retained by means of reducing water flow through the ctenidia and/or perhaps closing the ventral feeding tracts, as 
has been observed in various bivalve species (Ward et al. 1994, Beninger et al. 1997). The decline in clearance rate may also be due to other factors, such as reduction in retention efficiency of small particles $(<7 \mu \mathrm{m})$ by the ctenidia when there is an increase in seston, as observed in other bivalves (Wilson 1983, Barillé et al. 1993, 1997). The same inverse relationship of clearance rate to seston concentration has been described for other bivalves, such as Arctica islandica (Winter 1970), Cerastoderma edule (Navarro et al. 1992, 1994, Iglesias et al. 1996, Urrutia et al. 1996, Navarro \& Widdows 1997), $M$. chilensis (Navarro \& Winter 1982), and M. edulis (Winter 1976, Widdows et al. 1979, Kiørboe et al. 1980, 1981, Clausen \& Riisgård 1996). Other authors found that the clearance rate was independent of the concentration of seston (Møhlenberg \& Kiørboe 1981, Cranford et al. 1998), and yet others have observed increases in clearance rate with an increase in seston concentration (Newell \& Shumway 1993, Hawkins et al. 1996, Urrutia et al. 1996). These variations are related to the different types of particles in the seston and the range of seston concentration used in the studies cited (Hawkins et al. 2001).

Although the feeding activity of Mulinia edulis and Mytilus chilensis decreased with increasing seston concentration, the amount of seston and amount of organic matter filtered increased. It was also found that the increases in total and organic matter filtration by both species that occurred when the organic content of the diet decreased was due to a slight increase in clearance rate. This relationship has also been observed in other bivalves such as Cerastoderma edule (Navarro et al. 1994, Iglesias et al. 1996, Hawkins et al. 1998), Crassostrea gigas (Hawkins et al. 1998), and Mytilus edulis (Bayne et al. 1993).

The higher rates of clearance and filtration observed in Mytilus chilensis support the results from earlier studies that compared epifaunal non-siphonate species with infaunal siphonate species (Tenore \& Dunstan 1973, Foster-Smith 1975, Bacon et al. 1998). This difference may be related to the higher water-pumping rate in the pallial cavity of $M$. chilensis, a greater efficiency in the retention of small particles, and/or a larger ctenidial surface compared with the infaunal species. However, as Jørgensen \& Riisgård (1988) and Jørgensen (1990) demonstrated that frictional resistance to flow is very low even in long siphons, and Grizzle et al. (1992) demonstrated that siphonate taxa typically have greater inhalant pumping speeds than non-siphonate taxa, it is improbable that the waterpumping rate is lower in siphonate species. Although the retention efficiency of small particles was not examined, this was unlikely to have been a factor in the differences observed in clearance rates between the 2 species, since in the diet $80 \%$ of the particles were greater than $4 \mu \mathrm{m}$ in diameter, i.e. in the size range that is retained with $100 \%$ efficiency (Vahl 1973, Bayne \& Newell 1983). Accordingly, the most probable reason for the higher feeding rates in M. chilensis is its large ctenidia, which can retain larger quantities of particulate material than the small ctenidia of Mulinia edulis. The relationship between ctenidial area per unit weight and clearance rate has previously been described at interspecific (Foster-Smith 1975, Hawkins et al. 1990) and intraspecific (Jones et al. 1992, Bayne 1993) levels. Also, the greater feeding activity of $M$. chilensis could be related to its type of ctenidia and its superior capacity for processing the material that these retain: whereas Mulinia edulis is a homorhabdic eulamellibranch, $M$. chilensis is a homorhabdic filibranch. According to Ward et al. (1993) and Beninger et al. (1997), homorhabdic eulamellibranchs can transport retained particles toward the labial palps only by means of the ventral tracts, whereas homorhabdic filibranchs are able to transport them by both ventral and dorsal tracts.

\section{Rejection rate and pre-ingestive selection efficiency}

The capacity for processing particulate food is subject to certain limitations, above which excess retained food is rejected in the form of pseudofeces. It is not clear if this limitation is morphological or functional, or whether it is imposed by the digestive tract, the ctenidia and/or labial palps. According to Bayne et al. (1989), maximum ingestion coincides with the seston concentration at which pseudofeces production begins. In the present study, however, the highest ingestion rates for both species were obtained at seston concentrations above the threshold levels for pseudofeces production. It is thus probable that pseudofeces production did not arise from saturation of the digestive tract.

The threshold for production of pseudofeces in Mulinia edulis was higher than that in Mytilus chilensis. This was related to the lower quantity of material retained on the smaller ctenidia of $M$. edulis: the larger labial palps become saturated at seston concentrations higher than the saturation concentrations for $M$. chilensis, which has large ctenidia and small labial palps. Navarro et al. (1992) associated the higher threshold of pseudofeces production in Cerastoderma edule with this species' higher capacity to reduce clearance rates compared to $M$. edulis. This situation appears hardly probable for $M$. chilensis and M. edulis, since they have similar capacities for reducing their clearance rates (the slopes relating these rates to seston concentration were -0.61 for $M$. chilensis and -0.60 for $M$. edulis). On a better-quality diet, the threshold for pseudofeces production was higher in M. edulis, 
but not in M. chilensis. (C. edule showed similar behavior to that of M. edulis: Iglesias et al. 1996.) This, together with the low and sporadic production of pseudofeces by $M$. chilensis at low seston concentrations, may be an indication that the low rate is not due to morphological limitations or to digestive functions, but is rather a response that can be suppressed when no nutritional advantage is to be gained.

Above the threshold of pseudofeces production, Mulinia edulis rejected 11 to $80 \%$ and Mytilus chilensis 15 to $90 \%$ of filtered materials. The highest rejection percentages occurred for diets with high seston concentrations and low organic matter content, indicating that the production of pseudofeces in both bivalves is a mechanism that permits regulation of the rate of ingestion, especially when the diet is excessively concentrated and/or of low quality. The increase in the production of pseudofeces with increasing concentration and decreasing quality of the seston agrees with previous data for other bivalves (Kiørboe et al. 1980, Bayne et al. 1993, Iglesias et al. 1996, Hawkins et al. 1998). However, in some bivalves such as Mya arenaria, the production of pseudofeces was reported not to increase with increasing seston concentration (Bacon et al. 1998): this may have been due to the limited range of seston concentrations used in the measurements.

Release of pseudofeces by Mytilus chilensis was continuous compared with that by Mulinia edulis, in which accumulations of these biodeposits were observed to be periodically ejected by contraction of the siphons and rapid abduction of the valves. This behavior in $M$. edulis may be related to its long incurrent siphon, which impedes the removal of pseudofeces. Observations by Beninger et al. (1997) on the eulamellibranchs Mya arenaria and Spisula solidissima showed that the labia below the mouth may temporarily shut, thus accumulating excess material until this is trapped by the cilia of the labial palps and diverted toward the exit stream of the pseudofeces. The present study found that $M$. chilensis produced greater quantities of pseudofeces than $M$. edulis due to the greater amounts of material filtered by the former. Similar results were described in comparisons of other epibenthic and infaunal species: Placopecten magellanicus produced greater quantities of pseudofeces than Mya arenaria (Bacon et al. 1998) and M. edulis greater quantities than Mercenaria mercenaria (Tenore \& Dunstan 1973) and Cerstoderma edule (Hawkins et al. 1998).

Pseudofeces produced by both Mulinia edulis and Mytilus chilensis contained lower amounts of organic matter than were introduced with the seston diets, which suggests the presence of pre-ingestive mechanisms that allow rejection of particles of low organic content and ingestion of organically rich particles. This capacity has been recognised previously by numerous authors working with other bivalve species (Kiørboe \& Møhlenberg 1981, Newell \& Jordan 1983, Iglesias et al. 1992, Navarro et al. 1992). Some species however do not have this capacity (e.g. Venerupis pullastra: Foster-Smith 1975, Mya arenaria: Bacon et al. 1998, and Pinctada imbricata, Ward \& MacDonald 1996).

Pre-ingestive particle selection in bivalves occurs both at the ctenidia and at the labial palps (Ward et al. 1994, Beninger et al. 1997). It is not clear if selection of material is made on the basis of its chemical composition or physical characteristics of the particles related to their organic or inorganic nature. Some authors have suggested that hardness and flexibility may play an important role in the selection process (Bougrier et al. 1997). Other authors have suggested that the type of microalgae and its chemical composition are determining factors (Newell \& Jordan 1983, Shumway et al. 1985). Finally, some authors have demonstrated selection on the basis of particle size, whereby particles or microalgae of relatively large sizes are preferentially rejected (Defossez \& Hawkins 1997, Navarro \& Thompson 1997). In the present study, the pre-ingestive selection of particles with high organic content may be related to the capacity of the bivalves to recognise the chemical nature of the particles, or to some morphological characteristic linked to their organic content (e.g. size, density, form, flexibility, or hardness).

The capacity of Mulinia edulis and Mytilus chilensis for particle selection decreased with decreasing quality of the seston. In $M$. edulis this also decreased slightly when the quality of the seston was very high (>60\% organic matter) as observed in other bivalves (Hawkins et al. 1996, 1998, Iglesias et al. 1996, Wong \& Cheung 1999). The decline in selection efficiency with decreasing quantities of seston may be explained by the higher dilution of organic material with inorganic material, and the difficulty in perception of this by the receptors in the bivalves (Newell et al. 1989). The decrease in selection efficiency by $M$. chilensis fed seston of very high quality probably arose from the small nutritive advantage to be gained from increased selection on this type of diet, and to organic enrichment of the mucus accompying pseudofeces production (pseudofecal metabolic loss), which represents a high energetic cost (Bayne et al. 1993). The fact that $M$. edulis does not experience a reduction in selection efficiency with high-quality diets may be explained by the higher capacity of selection associated with its relatively large labial palps.

The selection efficiency of both bivalves increased markedly with increasing food supply, remaining relatively constant and high with the highest seston concentrations. This is in agreement with data of Hawkins 
et al. (1998) for Crassostrea gigas and Mytilus edulis, but in contrast to data for Cerastoderma edule, in which a decrease in efficiency selection was observed with increasing concentration of seston (Navarro \& Widdows 1997, Hawkins et al. 1998). Pseudofecal metabolic losses were most obvious at low seston concentrations, being responsible for negative selection efficiencies. Similar negative selections were observed when the quality of the food was low. Conversely, the high selection efficiency observed at high seston concentrations may have been due to the capacity of the labial palps to differentiate and separate particles with different levels of organic content.

Although the labial palps of Mulinia edulis are larger than those of Mytilus chilensis, their selection efficiency was similar. Other interspecific comparisons found correlations between palp size and selection efficiency (Kiørboe \& Møhlenberg 1981). Bacon et al. (1998) demonstrated that the epifaunal species Placopecten magellanicus was more efficient in rejecting inorganic particles than the infaunal Mya arenaria when seston concentrations were between 3 and $14 \mathrm{mg} \mathrm{l}^{-1}$, however these authors did not evaluate these results in reference to the relative sizes of the labial palps. As shown by Hawkins et al. (1990) for Cerastoderma edule and $M$. edulis, there may be a general tendency for the labial palps of infaunal species to be larger than those of epifaunal species. Other factors, such as the degree of specialisation of the labial palps and/or the ctenidia, may play an important role in the process of particle selection. Since the gills of $M$. chilensis are able to transport retained particles toward the mouth both by dorsal and ventral feeding tracts (Ward et al. 1993, Beninger \& St-Jean 1997), it is possible that qualitative particle separation may occur in the gills. This would compensate for the poor particle selection efficiency of its small labial palps. Conversely, the small size of the ctenidia in $M$. edulis results in particle selection by its relatively larger labial palps.

\section{Ingestion rate}

The ingestion rate of Mulinia edulis and Mytilus chilensis increased with increasing seston concentration and decreasing seston quality. The degree of regulation of material ingested was greater in $M$. chilensis, with a reduction in ingestion rate at high concentrations and low quality, while in $M$. edulis it remained constant. Morphological or functional saturation of the ctenidia, palps, or digestive tract may explain the decrease in ingestion rate at high seston concentrations, but for low concentrations and quality of seston this explanation does not apply. It is probable that with seston at high concentrations and/or of low quality, the efficiency of particle selection at the level of the labial palps declines and the reduction in ingestion rate represents a compensatory mechanism that permits maintenance of high absorption efficiency. Both the increase in and the regulation of the ingestion rate with increasing seston concentration have been observed in other bivalve species such as Cerastoderma edule (Navarro et al. 1994, Iglesias et al. 1996, Navarro \& Widdows 1997), Crassostrea gigas (Hawkins et al. 1998), M. edulis (Bayne et al. 1989), and $M$. mercenaria (Bricelj \& Malouf 1984).

There were no differences between total ingestion rate of the 2 species, although Mytilus chilensis filtered more food than Mulinia edulis: this is explainable by the higher proportion of material rejected by $M$. chilensis. In contrast, $M$. chilensis ingested more organic food than $M$. edulis, probably due to the larger amount of organic material it filtered. These results coincide with those of Hawkins et al. (1998), who reported the rate of ingestion of organic material of an epifaunal species ( $M$. edulis) to be greater than that of an infaunal species (Cerastoderma edule).

It has been reported that species better adapted to high-turbidity environments (infauna and species with siphons) regulate ingestion primarily by production of pseudofeces. Those not similarly adapted (epifaunal and non-siphonate species) regulate their ingestion rates by reduction in clearance rate (Foster-Smith 1975, Bricelj \& Malouf 1984, Bacon et al. 1998). Both species studied here had both mechanisms for regulating their ingestion rate. However, at low concentrations of seston and/or with high seston quality, reduction of clearance rate with increasing TPM was more marked than any increase in pseudofeces production. At median or high seston concentrations and/or with low seston quality, the situation was reversed. Regulation of the ingestion rate by means of coordination of the clearance rate and production of pseudofeces is a mechanism that contributes to maximisation of energy gain under varying conditions of food availability. Thus, a reduction in clearance rate is more beneficial than production of pseudofeces when the diet is of high quality, since it is practically impossible to optimise such a diet; in addition, the organic enrichment of the mucus that accompanies the production of pseudofeces would be an unnecessary energy expenditure. When, however, the diet is of low quality, it may be advantageous for bivalves not to reduce the clearance rate in order to filter large quantities of particles and thus be able to preferentially select and ingest particles of higher nutrient value.

Acknowledgements. The authors gratefully acknowledge Elías Díaz and Maritza Araneda for their help during the 
experiments. Thanks are also due to the staff of the field station of Yaldad, Chiloé, where most of the experimental study was done. This study was supported by a research grant to J.M.N. (FONDECYT 1000427), by a research grant to L.A.V. doctoral thesis (DID, Universidad Austral de Chile D-99-01) and by a fellowship to L.A.V. by DAAD (Deutscher Akademischer Austauschdienst, Programmabteilung Süd).

\section{LITERATURE CITED}

Asencio G, Clasing E, Herrera C, Stead R, Navarro J (1993) Copépodos harpacticoideos de las comunidades de Venus antiqua y Mulinia sp. en la planicie mareal de Yaldad, Quellón, Chiloé, Chile. Rev Chil Hist Nat 66:455-465

Bacon GS, MacDonald BA, Ward JE (1998) Physiological responses of infaunal (Mya arenaria) and epifaunal (Placopecten magellanicus) bivalves to variations in the concentration and quality of suspended particles I. Feeding activity and selection. J Exp Mar Biol Ecol 219:105-125

Barillé L, Prou J, Hérald M, Bourgrier S (1993) No influence of food quality, but ration-dependent retention efficiencies in the Japanese oyster Crassostrea gigas. J Exp Mar Biol Ecol 171:91-106

Barillé L, Prou J, Hérald M, Razet D (1997) Effects of high natural seston concentrations on the feeding, selection and absorption of the oyster Crassostrea gigas (Thunberg). J Exp Mar Biol Ecol 212:149-172

Bayne BL (1993) Feeding physiology of bivalves: time-dependence and compensation for changes in food availability. In: Dame RD (ed) Bivalve filter feeders in estuarine and coastal ecosystem processes. Springer-Verlag, Berlin, p 1-23

Bayne BL, Newell RD (1983) Rhysiological energetics of marine molluscs. In: Saleuddin ASM, Wilbur KM (eds) The mollusca, Vol 2(1). Academic Press, New York, p 407-515

Bayne BL, Hawkins AJS, Navarro E (1987) Feeding and digestion by the mussel Mytilus edulis L. (Bivalvia: Mollusca) in mixtures of silt and algal cells at low concentrations. J Exp Mar Biol Ecol 111:1-22

Bayne BL, Hawkins AJS, Eavarro N, Iglesias IP (1989) Effects of seston concentration of feeding, digestion and growth in the mussel Mytilus edulis. Mar Ecol Prog Ser 55:47-59

Bayne BL, Iglesias JIP, Hawkins AJS, Navarro E, Heral M, Delous-Paoli JM (1993) Feeding behavior of the mussel Mytilus edulis: responses to variations in quality and organic content of the seston. J Mar Biol Assoc UK 73: $813-829$

Beninger PG, St-Jean SD (1997) Particle processing on the labial palps of Mytilus edulis and Placopecten magellanicus (Mollusca: Bivalvia). Mar Ecol Prog Ser 147:117-127

Beninger PG, Dufour SC, Bourque J (1997) Particle processing mechanisms of the eulamellibranch bivalves Spisula solidissima and Mya arenaria. Mar Ecol Prog Ser 150: 157-169

Bougrier S, Hawkins AJS, Héral M (1997) Preingestive selection of different microalgal mixtures in Crassostrea gigas and Mytilus edulis, analysed by flow cytometry. Aquaculture 150:123-134

Bricelj VM, Malouf RE (1984) Influence of algal and suspended sediment concentrations on the feeding physiology of the hard clam Mercenaria mercenaria. Mar Biol 84: 155-165

Clasing EO, Navarro JM, Lardies MA, Stead RA (1998) Alimentación suspensívora-detritívora en bivalvos de la infauna, una estrategia dual para el aprovechamiento de la oferta alimentaria. Informe final proyecto Fondecyt 19511202, Universidad Austral de Chile, Valdivia
Clausen I, Riisgård HU (1996) Growth, filtration and respiration in the mussel Mytilus edulis: no evidence for physiological regulation of the filter-pump to nutritional needs. Mar Ecol Prog Ser 141:37-45

Cranford PJ, Emerson CW, Hargrave BT, Milligan TG (1998) In situ feeding and absorption responses of sea scallops Placopecten magellanicus (Gmelin) to storm-induced changes in the quantity and composition of the seston. J Exp Mar Biol Ecol 219:45-70

Defossez JM, Hawkins AJS (1997) Selective feeding in shellfish: size-dependent rejection of large particles within pseudofeces from Mytilus edulis, Ruditapes philippinarum and Tapes decussatus. Mar Biol 129:139-147

Falconer RA, Owens PH (1990) Numerical modelling of suspended sediment fluxes in estuarine waters. Estuar Coast Shelf Sci 31:745-762

Foster-Smith RL (1975) The effect of concentration of suspension on the filtration rates and pseudofaecal production for Mytilus edulis L Cerastoderma edule (L.) and Venerupis pullastra (Montagu). J Exp Mar Biol Ecol 17: $1-22$

Grizzle RE, Langan R, Howell WH (1992) Growth responses of suspension-feeding bivalves mollusks to changes in water flow: differences between siphonate and nonsiphonate taxa. J Exp Mar Biol Ecol 162:213-228

Guillard RRL (1974) Culture of phytoplankton for feeding marine invertebrates. In: Smith WL, Chanley MH (eds) Culture of marine invertebrate animals. Plenum Publishing, New York, p 29-60

Hawkins AJS, Navarro E, Iglesias JIP (1990) Comparative allometries of gut-passage time, gut content and metabolic faecal loss in Mytilus edulis and Cerastoderma edule. Mar Biol 105:197-204

Hawkins AJS, Smith RFM, Bayne BL, Herald M (1996) Novel observations underlying the fast growth of suspensionfeeding shellfish in turbid environments: Mytilus edulis. Mar Ecol Prog Ser 131:179-190

Hawkins AJS, Bayne BL, Bougrier S, Héral M, Iglesias JIP, Navarro E, Smith RFM, Urrutia MB (1998) Some general relationships in comparing the feeding physiology of suspension-feeding bivalve molluscs. J Exp Mar Biol Ecol 219:87-103

Hawkins AJS, Fang JG, Pascoe PL, Zhang JH, Zhang XL, Zhu MY (2001) Modelling short-term responsive adjustments in particle clearance rate among bivalve suspensionfeeders: separate unimodal effects of seston volume and composition in the scallop Chlamys farreri. J Exp Mar Biol Ecol 262:61-73

Iglesias JIP, Navarro E, Alvarez PJ, Armentia Y (1992) Feeding, particle selection and absorption in cockles Cerastoderma edule (L.) exposed to variable conditions of food concentration and quality. J Exp Mar Biol Ecol 162: $177-198$

Iglesias JIP, Urrutia MB, Navarro E, Alvarez-Jorna $\mathrm{P}$, Larretxea X, Bougrier S, Heral M (1996) Variability of feeding processes in the cockle Cerastoderma edule (L.) in response to changes in seston concentration and composition. J Exp Mar Biol Ecol 197:121-143

Jaramillo E, Mulsow S, Navarro R (1985) Intertidal and subtidal macroinfauna in the Queule River Estuary, south of Chile. Rev Chil Hist Nat 58:127-137

Jones HD, Richards OG, Southern TA (1992) Gill dimensions, water pumping rate and body size in the mussel Mytilus edulis L. J Exp Mar Biol Ecol 155:213-237

Jørgensen CB (1990) Bivalve filter feeding: hydrodynamics, bioenergetics, physiology and ecology. Olsen \& Olsen, Fredensborg 
Jørgensen CB, Riisgård HU (1988) Gill pump characteristics of the soft clam Mya arenaria. Mar Biol 99:107-109

Kiørboe T, Møhlenberg F (1981) Particle selection in suspension-feeding bivalves. Mar Ecol Prog Ser 5:291-296

Kiørboe T, Møhlenberg F, Nøhr O (1980) Feeding, particle selection and carbon absorption in Mytilus edulis in different mixtures of algae and resuspended bottom material. Ophelia 19:193-205

Kiørboe T, Møhlenberg F, Nøhr O (1981) Effect of suspended bottom material on growth and energetics in Mytilus edulis. Mar Biol 61:283-288

Møhlenberg F, Kiørboe T (1981) Growth and energetics in Spisula subtruncata (Da Costa) and the effect of suspended bottom material. Ophelia 20:79-90

Navarro JM, Thompson RJ (1996) Physiological energetics of the horse mussel Modiolus modiolus in a cold ocean environment. Mar Ecol Prog Ser 138:135-148

Navarro JM, Thompson RJ (1997) Biodeposition by the horse mussel Modiolus modiolus (Dillwyn) during the spring diatom bloom. J Exp Mar Biol Ecol 209:1-13

Navarro JM, Widdows J (1997) Feeding physiology of Cerastoderma edule in response to a wide range of seston concentrations. Mar Ecol Prog Ser 152:175-186

Navarro JM, Winter JE (1982) Ingestion rate, assimilation efficiency and energy balance in Mytilus chilensis in relation to body size and different algal concentrations. Mar Biol 67:255-266

Navarro E, Iglesias JIP, Ortega MM (1992) Natural sediment as food source for the cockle Cerastoderma edule (L.): effect of variable particle concentration on feeding, digestion and the scope for growth. J Exp Mar Biol Ecol 156: 69-87

Navarro JM, Clasing E, Urrutia G, Asencio G, Stead R, Herrera C (1993) Biochemical composition of the suspended particulate matter in a tidal flat of Southern Chile: an evaluation of its nutritive value. Estuar Coast Shelf Sci 37:59-73

Navarro E, Iglesias JIP, Ortega MM, Larrextrea X (1994) The basis for a functional response to variable food quality and quantity in cockles Cerastoderma edule (Bivalvia, Cardiidae). Physiol Zool 67:468-496

Newell CR, Shumway SE (1993) Grazing of natural particulates by bivalve molluscs: spatial and temporal perspective. In: Dame RD (ed) Bivalve filter feeders in estuarine and coastal ecosystem processes. Springer-Verlag, Berlin, p 85-148

Newell CR, Shumway SE, Cucci TL, Selvin R (1989) The effects of natural seston particle size and type on feeding rate, feeding selectivity and food resource availability for the mussel Mytilus edulis Linnaeus, 1758 at bottom culture sites in Maine. J Shellfish Res 8:187-196

Newell RIE, Jordan SJ (1983) Preferential ingestion of organic material by the American oyster Crassostrea virginica. Mar Ecol Prog Ser 12:47-53

Rojas CF (1984) Dinámica anual del seston en el estuario del Río Queule, IX Región. Rev Biol Mar 20:139-157

Shumway SE, Cucci TL, Newell RC, Yentsch CM (1985) Par-

Editorial responsibility: Roger Hughes (Contributing Editor), Bangor, Wales, UK ticle selection, ingestion and absorption in filter-feeding bivalves. J Exp Mar Biol Ecol 91:77-92

Sokal RR, Rohlf FJ (1979) Biometría, principios y métodos de la investigación biológica. Blume ediciones, Madrid

Strickland JDH, Parsons TR (1972) A practical handbook of seawater analysis, 2nd edn. Bull Fish Res Board Can 167:310

Tenore KR, Dunstan WM (1973) Comparison of feeding and biodeposition of three bivalves at different food levels. Mar Biol 21:190-195

Urrutia MB, Iglesias JIP, Navarro E, Prou J (1996) Feeding and absorption in Cerastoderma edule under environmental conditions in the bay of Marennes-Oleron (W. France). J Mar Biol Assoc UK 76:431-450

Vahl O (1973) Efficiency of particle retention in Chlamys islandica (OF Müller). Astarte 6:21-25

Ward JE, MacDonald BA (1996) Pre-ingestive feeding behaviors of two sub-tropical bivalves (Pinctada imbricata and Arca zebra): responses to an acute increase in suspended sediment concentration. Bull Mar Sci 59:417-432

Ward JE, MacDonald BA, Thompson RJ, Beninger PJ (1993) Mechanisms of suspension feeding in bivalves: resolution of current controversies by means of endoscopy. Limnol Oceanogr 38:265-272

Ward JE, Newell RIE, Thompson RJ, MacDonald BA (1994) In vivo studies of suspension-feeding processes in the Eastern oyster, Crassostrea virginica (Gmelin). Biol Bull 186:221-240

Widdows J (1985) Physiological procedures. In: Bayne BL, Brown DA, Burns K, Dixon DR and 5 others (eds) The effects of stress and pollution on marine animals. Praeger Scientific Publications, New York, p 161-178

Widdows J, Fieth P, Worrall CM (1979) Relationships between seston, available food and feeding activity in the common mussel Mytilus edulis. Mar Biol 50:195-207

Willows RI (1992) Optimal digestive investment: a model for filter feeders experiencing variable diets. Limnol Oceanogr 37:829-847

Wilson JH (1983) Retention efficiency and pumping rate of Ostrea edulis in suspensions of Isochrysis galbana. Mar Ecol Prog Ser 12:51-58

Winter JE (1970) Filter feeding and food utilization in Arctica islandica L. and Modiolus modiolus L. at different food concentrations. In: Steele JH (ed) Marine food chains. Oliver \& Boyd, Edinburgh, p 196-206

Winter JE (1976) Feeding experiments with Mytilus edulis L. at a small laboratory scale. II. The influence of suspended silt in addition to algal suspensions on growth. In: Persoone G, Jaspers E (eds) Proc 10th Eur Mar Biol Symp Vol 1. Universa Press, Wetteren, p 583-600

Winter JE, Navarro J, Román C, Chaparro O (1982) Programa de explotación de mitílidos, investigación científica básica. 2da parte. Gerencia de desarrollo AP81/39, Universidad Austral de Chile, Valdivia

Wong WH, Cheung SG (1999. Feeding behavior of the green mussel, Perna viridis (L.): responses to variation in seston quantity and quality. J Exp Mar Biol Ecol 236:191-207

Submitted: June 6, 2001, Accepted: January 14, 2002

Proofs received from author(s): August 12, 2002 